\title{
Editorial \\ Respiratory Syncytial Virus Infection in High-Risk Infants
}

\author{
Bernhard Resch*
}

Medical University of Graz, Austria

Respiratory syncytial virus (RSV) is the most important cause of lower respiratory tract infection (LRTI) in infants and children and is associated with substantial morbidity in both inpatient and outpatient settings. Overall RSV is associated with $20 \%$ of hospitalizations, $18 \%$ of emergency department visits and $15 \%$ of office visits for acute respiratory infections from November trough April [1]. Bronchiolitis hospitalizations in children younger than 2 years old significantly increased from $3.3 \%$ in 2002 to $5.5 \%$ in 2007, mainly because of RSV infections in US [2]. In Canada, inpatient care of RSV illness costs \$ 18 million (US dollars) yearly, accounting for 62 percent of the total cost of this disease [3]. The magnitude of the costs is understandable, since virtually all children become infected with RSV within two years after birth, and one percent requires hospitalization [4]. Recurrent wheezing following serious RSV associated LRTI is a common phenomenon of the disease that might persist until adulthood [5]. This Supplement of the Open Microbiology Journal focuses on that topic by a couple of review articles that represent a general clinical view. Therese Popow-Kraupp and Judith Aberle from the Institute of Clinical Virology of the Medical University of Vienna evaluate diagnostic tests for the detection of RSV including RSV rapid antigen detection tests from several specimen, nucleic acid assays and RTmultiplex PCRs as future trends. This chapter is followed by a review on the epidemiology of RSV infection in preterm infants by Bernhard Resch and Stefan Kurath from Austria and Paolo Manzoni from Italy. Especially due to the development of the humanized monoclonal antibody palivizumab that provides immunoprophylaxis against RSV when given monthly over the RSV season in high-risk

*Address correspondence to this author at the Division of Neonatology, Pediatric Department, Medical University of Graz, Auenbruggerplatz 30, A-8036 Graz, Austria; Tel: 0043316385 81134; Fax: 0043316385 2678;

E-mail: bernhard.resch@medunigraz.at infants like preterm infants this chapter represents important data for optimal guidance of this cost-intense prophylaxis. One of the leading experts world-wide on risk factors associated with severe RSV infection requiring hospitalization, Eric Simoes from Denver, USA, as the senior author together with authors from the Austrian RSV Study Group, report on patient groups at high risk for severe RSV disease, host-related factors increasing the severity of RSV disease and risk factors for the acquisition of the virus. At least Eric Simoes presents a short overview of risk scores that might be useful for the identification of late preterm infants at highest risk for severe RSV infection requiring palivizumab prophylaxis. A special population of high risk for severe RSV disease comprises the group of infants with neuromuscular impairment that is reported by Simon from the German RSV Study Group. The last chapter represents an overview of actual treatment strategies for mild and severe RSV LRTI done by the Austrian pulmonologist Ernst Eber. This Supplement of the Journal aims to put forward actual insights into the burden of RSV disease in young infants and children for both clinical and basic science researchers.

\section{REFERENCES}

[1] Hall CB, Weinberg G, Iwane M, Blumkin A,Ewards K, Staat M. The burden of Respiratory Syncytial Virus infection in young children. N Engl J Med 2009; 360: 588-98.

[2] Garcia C, Bhore R, Soriano-Fallas A, et al. Risk factors in children hospitalized with RSV Bronchiolitis versus non RSV Bronchiolitis. Pediatrics 2010; 126: 1453-60.

[3] Glezen WP. Morbidity associated with the major respiratory viruses. Pediatr Ann 1990; 19: 535-6, 538-40.

[4] Glezen WP, Taber LH, Frank AL, Kasel JH. Risk of primary infection and reinfection with respiratory-syncytial virus. Am J Dis Child 1986; 140: 543-6.

[5] Sigurs N, Aljassim F, Kjellman B, et al. Asthma and allergy patterns over 18 years after severe RSV bronchiolitis in the first year of life. Thorax 2010; 65: 1045-52.

(C) Bernhard Resch; Licensee Bentham Open.

This is an open access article licensed under the terms of the Creative Commons Attribution Non-Commercial License

(http://creativecommons.org/licenses/_by-nc/3.0/) which permits unrestricted, non-commercial use, distribution and reproduction in any medium, provided the work is properly cited. 